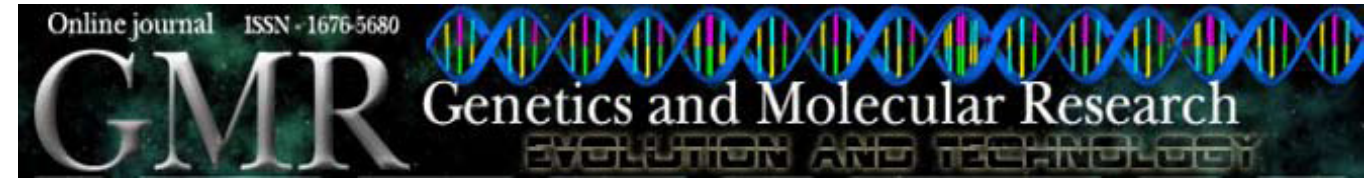

\title{
Mutagenic potential of water from Pelotas Creek in Rio Grande do Sul, Brazil
}

\author{
T.C.O. Santos ${ }^{1}$, L.F. Maciel ${ }^{1}$, K.S. Leal ${ }^{1}$, A.E.N. Bender ${ }^{1}$, T.S. Paiva ${ }^{1}$, \\ G.L. Garcias ${ }^{2}$ and M.G. Martino-Roth ${ }^{1}$ \\ ${ }^{1}$ Laboratório de Genética, Centro de Ciências da Vida e da Saúde, \\ Universidade Católica de Pelotas, Pelotas, RS, Brasil \\ ${ }^{2}$ Departamento de Zoologia e Genética, Instituto de Biologia, \\ Universidade Federal de Pelotas, Pelotas, RS, Brasil \\ Corresponding author: M.G. Martino-Roth \\ E-mail: martino@phoenix.ucpel.tche.br
}

Genet. Mol. Res. 8 (3): 1057-1066 (2009)

Received April 3, 2009

Accepted June 18, 2009

Published September 1, 2009

\begin{abstract}
Water resource degradation is one of mankind's greatest worries, as it causes direct and indirect damage to the associated biota. We initiated a water monitoring study in Pelotas Creek in 2003 in order to assess the mutagenic effect of the creek's waters. Allium cepa cells exposed to water samples and a chronically exposed macrophyte were analyzed, through evaluation of the mitotic index, mitotic anomalies, interphase anomalies, and total anomalies. Five points were chosen along the lower course of Pelotas Creek, from which water samples and floating pennywort (Hydrocotyle ranunculoides, Apiaceae) were collected in 2006 and 2007. The enteric bacterium Escherichia coli was found at all sampling points; in the physical-chemical analysis, a few variables exceeded permitted limits, $\mathrm{pH}$ (from 6 to 9), chloride (250 $\mathrm{mg} / \mathrm{L}$ ), hardness (from 10 to $200 \mathrm{mg} \mathrm{CaCO}_{3} / \mathrm{L}$ ), and conductivity (100 $\mu \Omega / \mathrm{cm}$ ). There was an increased number of cytogenetic anomalies in exposed A. cepa cells and in the pennywort in 2006 relative to 2007, which may be explained by the increased rainfall, which was three times greater in 2007 at some stations than in 2006.
\end{abstract}

Key words: Pelotas Creek; Hydrocotyle ranunculoides; Allium cepa; Mutagenicity 


\section{INTRODUCTION}

Water, an indispensable resource for the survival of every species, exerts a decisive influence on populations' quality of life (Ferreira and Cunha, 2005). During the last few decades, there has been an increase in the interest of the scientific community and regulatory agencies relative to the detection, knowledge, and control of environmental agents responsible for harm to human health and ecosystem sustainability (Bickham et al., 2000; Silva and Fonseca, 2003; Matsumoto et al., 2006).

Rivers that flow through metropolitan areas are a major source of drinking water for the population living in such areas. Industrial, domestic, agricultural, and other kinds of waste are dumped into those rivers; consequently, the pollution of their waters may become a huge problem for people's health and well-being, as well as for the native aquatic biota found in those river's ecosystems (Ohe et al., 2003; Egito et al., 2007). Thus, it is fundamental that water resources have appropriate physical-chemical conditions for use by living beings, contain substances essential to life, and be free from other substances that could cause damaging effects to organisms (Braga et al., 2002).

Biological monitoring consists of an assessment tool for the response of the biological communities to changes in the original environmental conditions, as they reflect the full ecological integrity of ecosystems. Toxicological assays, among others, are commonly used to determine organism sensitivity to concentrations of toxic substances, while the conventional methods (physical-chemical parameters) yield only partial results, that is, they only reflect the sampling moment (Alba-Tercedor, 1994).

Mutagenicity tests aim at detecting and understanding the action of certain substances called genotoxins on organisms, specifically nucleic acids, and especially DNA (Pereira et al., 2002). The use of bioassays with plants for assessing genotoxicity and in situ monitoring is very common throughout the world. The most commonly used bioassays are the micronucleus test, the genetic mutation test, and the test of chromosomal aberrations in metaphase. However, a very old test that assesses the chromosomal anomalies in anaphase-telophase (mitotic cycle anomalies) is still widely used, because it is a relatively simple and sensitive test. Using such a method, it is possible to detect aberrant anaphases, which along with the mitotic index, show the mutagenic potential of the waters examined. Besides, the test may be conducted with plans from the river, which would indicate the actual genotoxic impact for the chronically exposed organism population in the region (Lazutka et al., 2003; Reifferscheid et al., 2008).

Aquatic macrophytes are plants that are visible to the naked eye, whose photosynthesizing parts are permanently, or during several months every year, fully or partially submerged in fresh or salty water, or floating in it (Irgang and Gastal Júnior, 1996). As the role of aquatic macrophytes in the balance of limnic ecosystems became evident, research on such communities started to receive more attention from scientists from all over the world (Esteves, 1998).

Among the plant test systems Allium cepa $\mathrm{L}$. is the most commonly used plant for studies of chromosomal aberrations: its bulbs produce a large number of roots in a short time interval (the cell cycle is approximately $20 \mathrm{~h}$ ) and the chromosomes are of a relatively large size (Evandri et al., 2000). The Allium cepa test has proved to be a great research tool to assess the genotoxicity of known chemical substances, complex mixtures, beverages, and industrial waste (Fiskesjö, 1988; Rank and Nielsen, 1997; Leme and Marin-Morales, 2008). 
Pelotas Creek is about $60 \mathrm{~km}$ in length, being the largest water course in the city of Pelotas. It begins in the District of Cascata, near the border with Canguçu city, at an altitude of $200 \mathrm{~m}$. It follows a well-defined east-west direction, until, in the District of Laranjal, near Patos Lagoon, it abruptly changes direction, forming an "elbow", and starts to run north-south, until draining into São Gonçalo Channel. It starts in Cascata, then separates the District of Quilombo from Cascata and Cerrito Alegre in Monte Bonito; its low course is almost fully located within the District of Colônia Z-3, where it runs through floodplains. Among its best known crossings are the bridges of Retiro (BR-116), Cordeiro de Faria, and Laranjal. It has, in its lower course, a waterworks plant to supply the city with water (Rosa, 1985).

The aim of this study was to determine the mutagenic effect of the creek's waters through monitoring with the Allium cepa test and examining the chronically exposed macrophytes, by determining the mitotic index (MI), mitotic anomalies (MA), interphase anomalies (IA), and total anomalies (TA), as well as physical-chemical and microbiological analyses of the waters in the years 2006 and 2007.

\section{MATERIAL AND METHODS}

Samplings conducted in the lower course of Pelotas Creek (Figure 1) were seasonal and took place in the period from 2006 to 2007. Five points were chosen along the lower course of the creek: Station 1 - Cascalho village (31 $\left.{ }^{\circ} 41^{\prime} 42.8^{\prime \prime S} 52^{\circ} 16^{\prime} 32.0^{\prime \prime} \mathrm{W}\right)$; Station 2 - upstream from Frigorífico Miramar (31 $\left.44^{\prime} 42.1^{\prime \prime S} 52^{\circ} 16^{\prime} 34.5^{\prime \prime} \mathrm{W}\right)$; Station 3 - upstream from Vila da

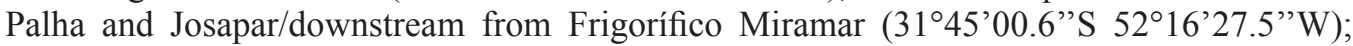
Station 4 - upstream from Marina Ilha Verde and Recanto de Portugal neighborhoods/downstream from Vila da Palha and Josapar (31 $\left.{ }^{\circ} 45^{\prime} 18.1^{\prime \prime S} 52^{\circ} 17^{\prime} 12.7^{\prime \prime} \mathrm{W}\right)$; Station 5 - upstream from São Gonçalo Channel/downstream from Marina Ilha Verde and Recanto de Portugal neighborhoods (31 ${ }^{\circ} 45^{\prime} 35.4^{\prime \prime} \mathrm{S} 52^{\circ} 17^{\prime} 11.5$ ”'W) (Figure 2).

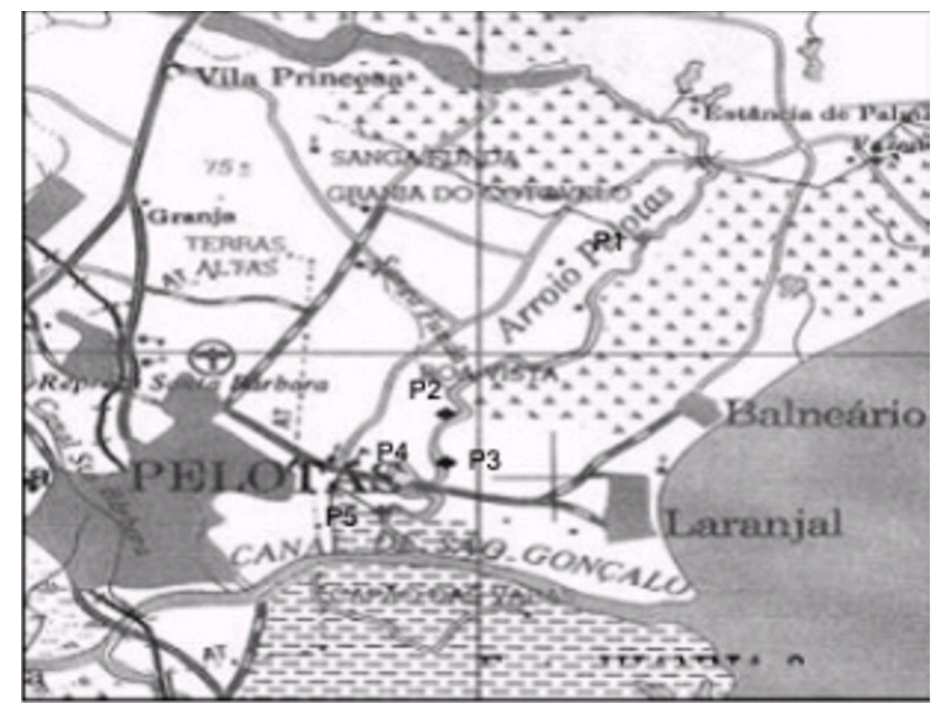

Figure 1. Map showing the sampling points (P1-P5) along the lower course of Pelotas Creek. 


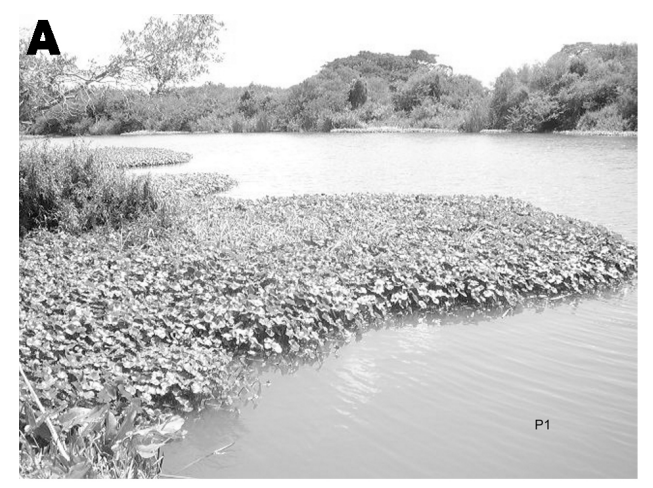

B
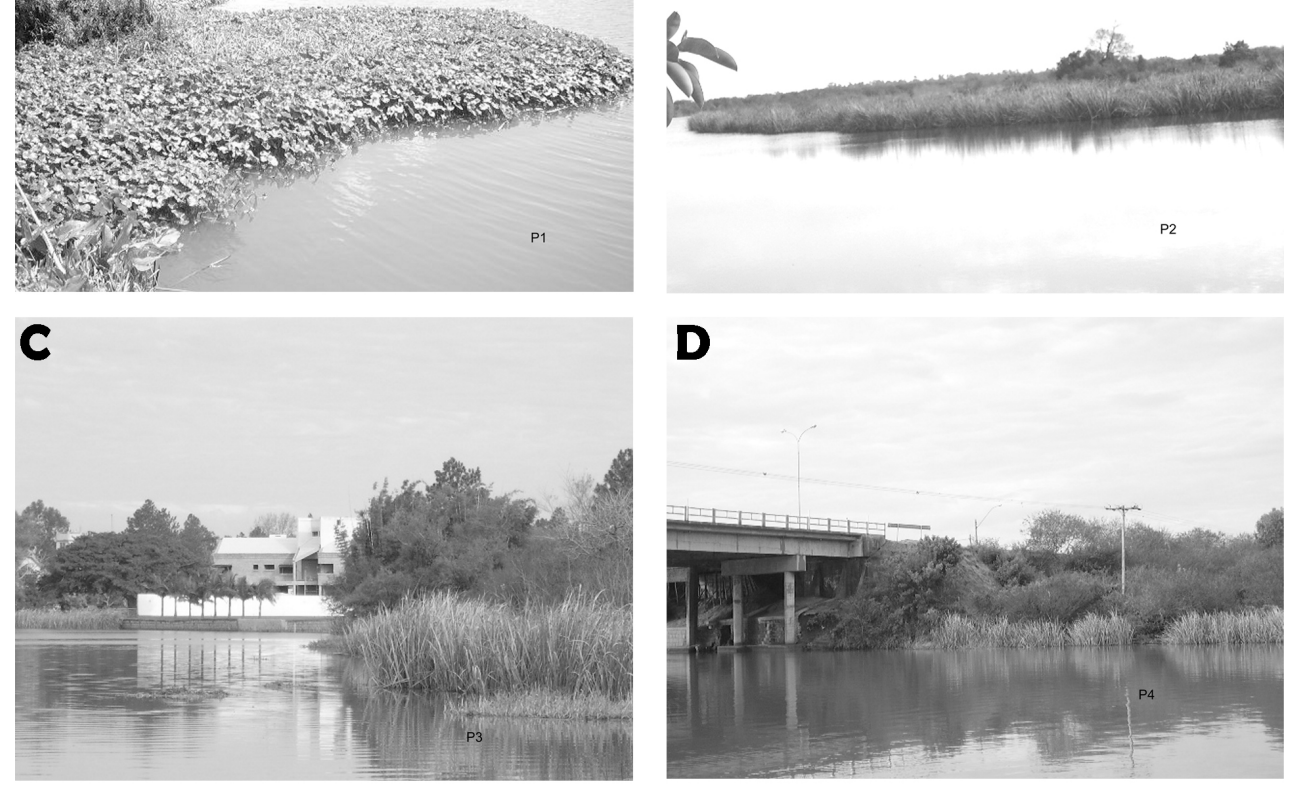

D

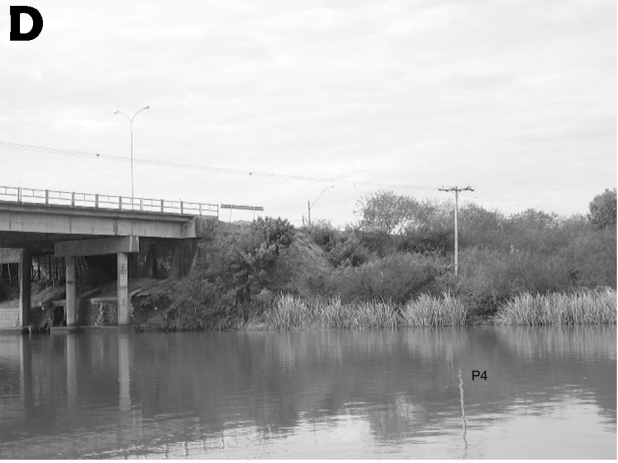

$\mathbf{E}$

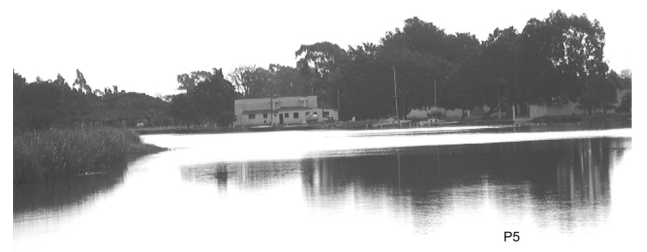

Figure 2. Pictures of each sampling point (P1-P5) A. Point 1: Cascalho village; B. Point 2: upstream from Frigorífico Miramar; C. Point 3: upstream from Vila da Palha; D. Point 4: upstream from Marina Ilha Verde and Recanto de Portugal neighborhoods; E. Point 5: upstream from São Gonçalo Channel.

For the cytogenetic analysis, conducted in Laboratório de Genética at Universidade Católica de Pelotas, chronically exposed aquatic macrophytes were used, and also the Allium cepa test. Random samples of the macrophyte Hydrocotyle ranunculoides were collected from each station. Root tips were collected and fixed in Carnoy's fixative. After $24 \mathrm{~h}$, they were kept in $70 \%$ ethanol. Four replications were performed for each point sampled (Figure 3). 

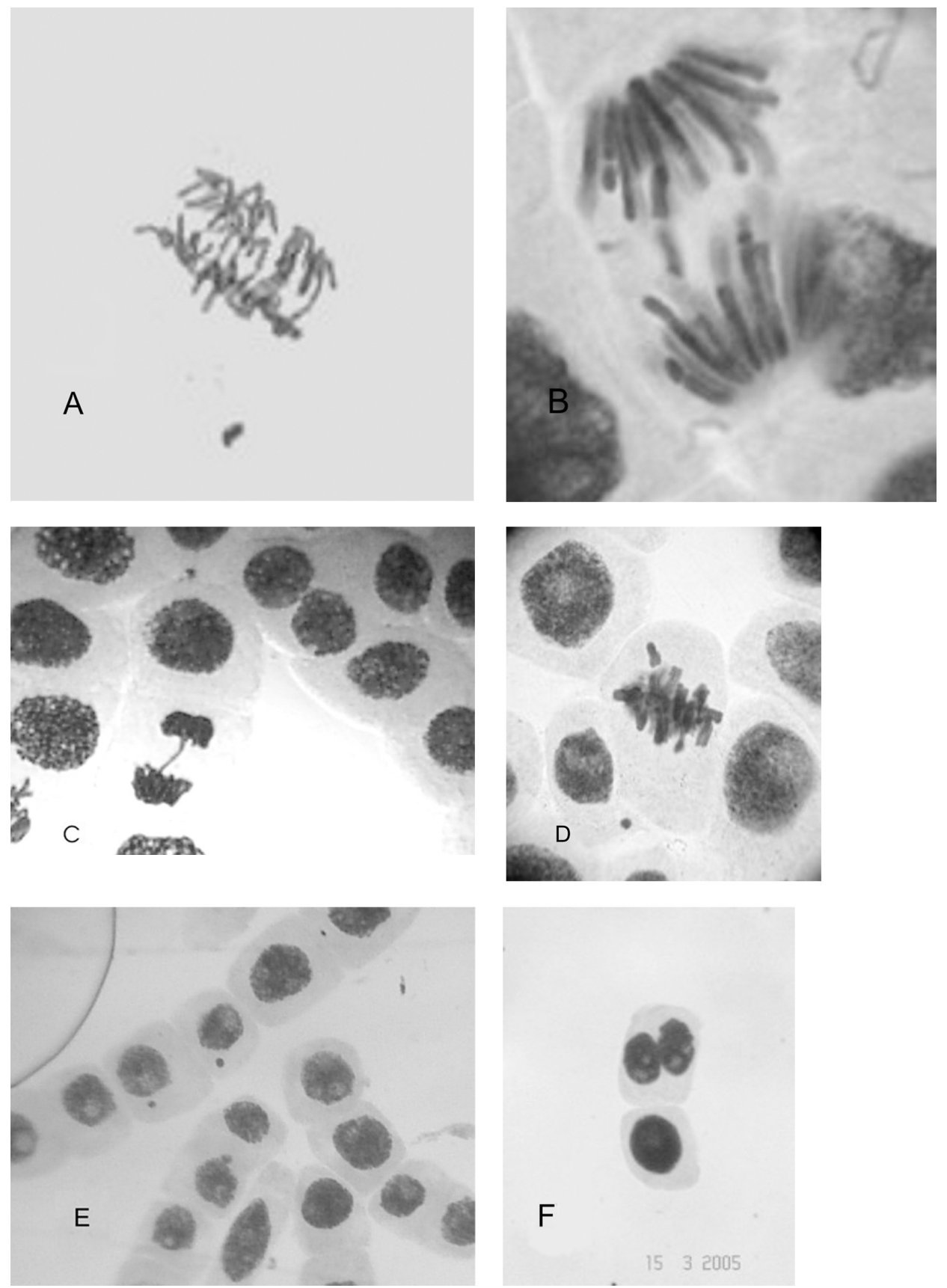

Figure 3. Cell changes analyzed in Hydrocotyle ranunculoides and Allium cepa. A. Multipolar anaphase. B. Chromosome lost in anaphase. C. Bridge in telephase. D. Chromosome lost in metaphase. E. Cell with micronucleus. F. Binucleated cell. 
For the Allium cepa test, bulbs were placed in bottles with drinking water at room temperature to develop roots. When the roots reached $0.5 \mathrm{~cm}$, they were placed in the water sampled from each point in Pelotas Creek, for $48 \mathrm{~h}$. The root tips were collected and fixed the same way as the macrophytes, carrying out four replications for each point. The water obtained through a Milli-Q filter was used in preparing a negative control.

For the preparation of slides, meristems were washed in distilled water (three times), hydrolyzed in $5 \mathrm{~N} \mathrm{HCl}$ for $10 \mathrm{~min}$, then washed again and kept in distilled water for $5 \mathrm{~min}$, and later crushed with acetic orcein, 2:1.

Eight thousand cells were found per point, using a binocular light microscope, with 100X objective lenses and 10X eyepieces. The analysis included MI and MA: anaphasic bridges, anaphasic fragments, lost chromosomes, metaphasic delay; IA: cells with micronucleus, binucleated cells or with linked nuclei, and TA: mitotic and interphasic.

For the physical-chemical analysis, water was collected from the five points in Pelotas Creek in bottles, which were taken to Laboratório de Química Ambiental at Universidade Católica de Pelotas, where analyses were performed regarding dissolved oxygen, $\mathrm{pH}$, acidity, alkalinity, chloride, hardness, and conductivity, following the methods described by the American Public Health Association, American Water Work Association, Water Pollution Control Federation (1998).

Water was also collected from the five stations in sterilized $100-\mathrm{mL}$ bottles for microbiological analysis. The samples were taken to Laboratório de Microbiologia at Universidade Católica de Pelotas, where $1 \mathrm{~mL}$ of Pelotas Creek's water was added in triplicate to liquid medium for Escherichia coli (medium EC). Afterward, the cultures were incubated at $44 \pm 0.2^{\circ} \mathrm{C}$ for 24 to $48 \mathrm{~h}$, in order to assess gas production, proof that identifies the presence or absence of $E$. coli, according to the method described by the American Public Health Association, American Water Work Association, Water Pollution Control Federation (1998).

For the statistical analysis, a database was built using the SPSS statistical program for Windows, version 10.0, using the Kruskal-Wallis test and the Mann-Whitney U-test, with odds ratio at 0.05 or lower.

\section{RESULTS AND DISCUSSION}

The lower Pelotas Creek was assessed regarding the mutagenic potential of its waters, through an analysis of the frequency of MA, IA, TA, and MI, at five defined sampling points for the four seasons of the year. This study, which started in 2003 and included the years 2004, 2005, 2006, and 2007, analyzed the chronically exposed plant Hydrocotyle ranunculoides, found at all locations. Only in 2006, besides this plant, the Allium cepa test and the microbiological analysis were concomitantly performed; in 2005, physicalchemical analysis was introduced.

In 2006, the sampling stations were compared among themselves and with the negative control for each station. It was found that during the summer, Point 1 - Cascalho village - was similar to the negative control and significantly different from the others, which showed high TA $(\mathrm{P}=0.037)$ and MA $(\mathrm{P}=0.026)$ frequencies. In the other seasons in 2006, the assessed points did not differ among themselves or relative to the negative 
control (Table 1). Such fact may have been influenced by a lower seasonal mean rain level than that found in 2007. The microbiological analysis detected the presence of $E$. coli at all points assessed. According to Resolution No. 357 by CONAMA, from 2005, $E$. coli is the only species in the group of thermotolerant coliforms whose single habitat is the human bowel and that of homoeothermic animals, where it is found at high densities. Therefore, this analysis indicates fecal contamination of the creek's water. In the physical-chemical analysis (Table 2), $\mathrm{pH}$ showed values within the protective criteria for aquatic life, which is established between 6 and 9 (CONAMA, 2005). According to Resolution No. 357 by CONAMA, 2005, which establishes the chloride limits at $250 \mathrm{mg} / \mathrm{L}$, the year 2006 showed values above the limit determined for the months of summer and fall at all points, with the exception of Point 1 in the fall. Hardness varies from 10 to 200 $\mathrm{mg} \mathrm{CaCO}_{3} / \mathrm{L}$ in natural fresh waters (Baumgarten and Pozza, 2001); for this variable, the behavior in the creek was similar to that of chloride. Conductivity showed values above $100 \mu \Omega / \mathrm{cm}$, virtually at all stations and most points, which may indicate impacted environments (CETESB, 2007).

\begin{tabular}{|c|c|c|c|c|c|c|c|c|c|}
\hline \multirow[t]{2}{*}{ Points } & \multirow[t]{2}{*}{ Variables } & \multicolumn{4}{|c|}{2006} & \multicolumn{4}{|c|}{2007} \\
\hline & & Summer & Fall & Winter & Spring & Summer & Fall & Winter & Spring \\
\hline \multirow[t]{4}{*}{ Control } & MI & $11.73 \%$ & $10.35 \%$ & $8.37 \%$ & $10.10 \%$ & $3.80 \%$ & $1.14 \%$ & $3.04 \%$ & $3.86 \%$ \\
\hline & MA & $3.00 \pm 2.58$ & $12.50 \pm 9.46$ & $12.50 \pm 9.57$ & $8.50 \pm 4.65$ & $13.00 \pm 5.94$ & $5.75 \pm 0.95$ & $12.25 \pm 2.06$ & $14.25 \pm 2.36$ \\
\hline & IA & $5.25 \pm 2.63$ & $4.25 \pm 3.30$ & $0.50 \pm 1.00$ & $3.50 \pm 1.91$ & $1.00 \pm 0.81$ & $0.50 \pm 0.57$ & $0.50 \pm 1.00$ & $0.00 \pm 0.00$ \\
\hline & TA & $8.25 \pm 1.50$ & $16.75 \pm 6.65$ & $13.00 \pm 10.39$ & $12.00 \pm 4.54$ & $14.00 \pm 6.27$ & $6.25 \pm 0.95$ & $12.75 \pm 2.75$ & $14.25 \pm 2.36$ \\
\hline \multirow[t]{4}{*}{ Point 1} & MI & $5.99 \%$ & $10.40 \%$ & $7.43 \%$ & $7.55 \%$ & $6.38 \%$ & $3.58 \%$ & $3.45 \%$ & $4.12 \%$ \\
\hline & MA & $7.33 \pm 10.61$ & $26.00 \pm 22.73$ & $16.66 \pm 12.80$ & $23.50 \pm 18.76$ & $20.60 \pm 14.09$ & $9.00 \pm 5.88$ & $14.25 \pm 5.85$ & $22.00 \pm 4.96$ \\
\hline & IA & $2.33 \pm 1.50$ & $7.50 \pm 8.11$ & $2.50 \pm 2.07$ & $1.33 \pm 1.03$ & $2.60 \pm 2.19$ & $2.25 \pm 2.21$ & $0.75 \pm 0.95$ & $0.25 \pm 0.50$ \\
\hline & $\mathrm{TA}$ & $9.66 \pm 9.17$ & $33.50 \pm 26.29$ & $19.16 \pm 14.68$ & $24.83 \pm 18.11$ & $23.20 \pm 14.44$ & $11.25 \pm 5.12$ & $15.00 \pm 5.35$ & $22.25 \pm 4.78$ \\
\hline \multirow[t]{4}{*}{ Point 2} & MI & $8.98 \%$ & $8.70 \%$ & $7.34 \%$ & $5.52 \%$ & $6.99 \%$ & $3.14 \%$ & $2.32 \%$ & $3.79 \%$ \\
\hline & MA & $14.50 \pm 10.74$ & $19.83 \pm 17.57$ & $17.33 \pm 8.77$ & $22.16 \pm 26.63$ & $28.00 \pm 9.72$ & $12.00 \pm 10.83$ & $14.50 \pm 8.34$ & $15.00 \pm 5.03$ \\
\hline & IA & $5.83 \pm 3.81$ & $6.50 \pm 3.56$ & $4.00 \pm 5.96$ & $3.33 \pm 3.55$ & $2.60 \pm 2.19$ & $1.50 \pm 1.00$ & $1.25 \pm 0.95$ & $0.00 \pm 0.00$ \\
\hline & $\mathrm{TA}$ & $20.33 \pm 14.12$ & $26.33 \pm 19.31$ & $21.33 \pm 10.87$ & $25.50 \pm 25.05$ & $30.60 \pm 11.19$ & $13.50 \pm 11.12$ & $15.75 \pm 7.63$ & $15.00 \pm 5.03$ \\
\hline \multirow[t]{4}{*}{ Point 3} & MI & $8.88 \%$ & $8.26 \%$ & $6.32 \%$ & $7.23 \%$ & $3.94 \%$ & $2.67 \%$ & $3.40 \%$ & $4.20 \%$ \\
\hline & MA & $22.50 \pm 9.77$ & $13.83 \pm 4.07$ & $14.66 \pm 6.40$ & $21.83 \pm 23.60$ & $19.40 \pm 12.52$ & $8.25 \pm 1.25$ & $20.75 \pm 13.09$ & $20.75 \pm 2.98$ \\
\hline & IA & $14.50 \pm 12.91$ & $8.33 \pm 7.42$ & $1.83 \pm 1.83$ & $3.33 \pm 3.98$ & $3.60 \pm 1.14$ & $1.50 \pm 1.73$ & $1.00 \pm 0.81$ & $0.25 \pm 0.50$ \\
\hline & $\mathrm{TA}$ & $37.00 \pm 13.20$ & $22.16 \pm 8.44$ & $16.50 \pm 7.06$ & $25.16 \pm 26.70$ & $23.00 \pm 12.70$ & $9.75 \pm 2.75$ & $21.75 \pm 13.67$ & $21.00 \pm 2.94$ \\
\hline \multirow[t]{4}{*}{ Point 4} & MI & $11.03 \%$ & $8.12 \%$ & $8.69 \%$ & $6.37 \%$ & $4.65 \%$ & $3.32 \%$ & $1.98 \%$ & $3.97 \%$ \\
\hline & MA & $31.16 \pm 25.87$ & $19.16 \pm 10.45$ & $22.33 \pm 9.30$ & $17.83 \pm 14.85$ & $21.60 \pm 10.26$ & $10.00 \pm 6.00$ & $6.75 \pm 3.86$ & $18.50 \pm 2.08$ \\
\hline & IA & $8.16 \pm 9.90$ & $4.66 \pm 1.86$ & $1.50 \pm 1.76$ & $1.66 \pm 1.03$ & $1.00 \pm 1.22$ & $0.75 \pm 0.50$ & $0.25 \pm 0.50$ & $1.00 \pm 0.81$ \\
\hline & $\mathrm{TA}$ & $39.33 \pm 33.27$ & $23.83 \pm 10.34$ & $23.83 \pm 9.53$ & $19.50 \pm 15.39$ & $22.60 \pm 11.08$ & $10.75 \pm 6.18$ & $7.00 \pm 4.08$ & $19.50 \pm 2.88$ \\
\hline \multirow[t]{4}{*}{ Point 5} & MI & $10.81 \%$ & $5.13 \%$ & $5.96 \%$ & $6.79 \%$ & $3.11 \%$ & $2.70 \%$ & $3.23 \%$ & $4.00 \%$ \\
\hline & MA & $25.16 \pm 19.46$ & $9.16 \pm 6.24$ & $14.66 \pm 13.66$ & $19.50 \pm 14.25$ & $18.80 \pm 10.37$ & $13.00 \pm 10.86$ & $14.50 \pm 2.88$ & $17.25 \pm 5.12$ \\
\hline & IA & $5.16 \pm 4.62$ & $4.66 \pm 3.55$ & $3.16 \pm 2.13$ & $7.00 \pm 6.63$ & $2.60 \pm 2.60$ & $0.25 \pm 0.50$ & $0.25 \pm 0.50$ & $0.25 \pm 0.50$ \\
\hline & TA & $30.33 \pm 20.18$ & $13.83 \pm 7.67$ & $17.83 \pm 12.98$ & $26.50 \pm 16.47$ & $21.40 \pm 9.81$ & $13.25 \pm 10.81$ & $14.75 \pm 2.98$ & $17.50 \pm 5.19$ \\
\hline
\end{tabular}

$\mathrm{MI}=$ mitotic index; $\mathrm{MA}=$ mitotic anomalies; $\mathrm{IA}=$ interphase anomalies; $\mathrm{TA}=$ total anomalies. 


\begin{tabular}{|c|c|c|c|c|c|c|c|c|c|}
\hline \multirow[t]{2}{*}{ Point } & \multirow[t]{2}{*}{ Variable } & \multicolumn{4}{|c|}{2006} & \multicolumn{4}{|c|}{2007} \\
\hline & & Summer & Fall & Winter & Spring & Summer & Fall & Winter & Spring \\
\hline \multirow[t]{6}{*}{ Point 1} & Acidity & 11.67 & 10.69 & 11.71 & 2.93 & 17.56 & 21.46 & 19.51 & 12.39 \\
\hline & Alkalinity & 27.14 & 21.84 & 28.26 & 25.50 & 58.53 & 40.60 & 68.76 & 48.72 \\
\hline & Chloride & 689.77 & 47.57 & 8.31 & 44.30 & 68.30 & 4.77 & 12.39 & 15.09 \\
\hline & Hardness & 220.00 & 35.00 & 31.00 & 40.00 & 36.00 & 15.00 & 9.00 & 20.00 \\
\hline & $\mathrm{pH}$ & 6.60 & 6.20 & 6.76 & 6.90 & 6.95 & 6.48 & 7.33 & 6.90 \\
\hline & Conductivity & 3050.00 & 259.00 & 80.70 & 206.10 & 87.50 & 37.90 & 50.60 & 92.00 \\
\hline \multirow[t]{6}{*}{ Point 2} & Acidity & 0 & 4.86 & 29.27 & 1.95 & 11.71 & 19.51 & 13.66 & 14.16 \\
\hline & Alkalinity & 37.19 & 30.94 & 30.60 & 35.70 & 58.53 & 40.60 & 66.85 & 54.81 \\
\hline & Chloride & 4138.59 & 689.77 & 7.38 & 166.14 & 320.28 & 4.77 & 8.58 & 21.13 \\
\hline & Hardness & 926.00 & 300.00 & 50.00 & 83.00 & 43.00 & 16.00 & 11.00 & 23.00 \\
\hline & $\mathrm{pH}$ & 8.30 & 6.80 & 6.18 & 7.55 & 6.86 & 6.49 & 7.29 & 7.00 \\
\hline & Conductivity & 12725.00 & 3600.00 & 84.50 & 551.50 & 245.80 & 42.50 & 51.00 & 116.20 \\
\hline \multirow[t]{6}{*}{ Point 3} & Acidity & 5.84 & 11.67 & 17.56 & 2.93 & 11.71 & 17.56 & 13.66 & 14.16 \\
\hline & Alkalinity & 54.27 & 35.04 & 38.76 & 39.78 & 52.68 & 44.66 & 70.77 & 56.84 \\
\hline & Chloride & 2568.78 & 975.19 & 15.69 & 167.06 & 343.36 & 6.67 & 11.44 & 20.12 \\
\hline & Hardness & 940.00 & 400.00 & 33.00 & 90.00 & 133.00 & 18.00 & 9.00 & 22.00 \\
\hline & $\mathrm{pH}$ & 7.70 & 6.60 & 6.60 & 7.67 & 6.87 & 6.38 & 7.50 & 7.40 \\
\hline & Conductivity & 11575.00 & 4950.00 & 114.10 & 583.40 & 838.70 & 50.40 & 61.50 & 109.30 \\
\hline \multirow[t]{6}{*}{ Point 4} & Acidity & 0.98 & 9.53 & 33.17 & 1.95 & 11.71 & 15.61 & 17.56 & 10.62 \\
\hline & Alkalinity & 47.24 & 35.04 & 32.64 & 37.74 & 60.48 & 42.63 & 57.30 & 54.81 \\
\hline & Chloride & 3187.19 & 1189.25 & 15.69 & 167.06 & 564.88 & 5.72 & 9.54 & 16.09 \\
\hline & Hardness & 946.00 & 550.00 & 47.00 & 98.00 & 140.00 & 16.00 & 41.00 & 21.00 \\
\hline & $\mathrm{pH}$ & 7.90 & 6.70 & 6.20 & 7.54 & 6.83 & 6.58 & 7.20 & 7.40 \\
\hline & Conductivity & 13400.00 & 6200.00 & 101.30 & 585.20 & 879.60 & 42.50 & 57.60 & 105.20 \\
\hline \multirow[t]{6}{*}{ Point 5} & Acidity & 0.98 & 8.75 & 42.92 & 2.93 & 13.66 & 17.56 & 9.76 & 8.85 \\
\hline & Alkalinity & 46.23 & 40.04 & 38.76 & 41.82 & 58.53 & 40.60 & 68.75 & 54.81 \\
\hline & Chloride & 4447.80 & 1902.80 & 22.15 & 153.22 & 77.53 & 6.67 & 10.49 & 9.05 \\
\hline & Hardness & 1164.00 & 750.00 & 56.00 & 83.00 & 200.00 & 18.00 & 21.00 & 21.00 \\
\hline & $\mathrm{pH}$ & 8.30 & 7.00 & 5.90 & 7.65 & 6.80 & 6.49 & 7.30 & 7.30 \\
\hline & Conductivity & 16025.00 & 8850.00 & 114.90 & 543.50 & 1278.00 & 47.30 & 65.30 & 92.40 \\
\hline
\end{tabular}

In 2007, the sampling points were also compared among themselves and with the negative control for each season of the year. No change was found relative to the negative control, and no difference was found in the assessed variables among the points. In the microbiological analysis, no difference was found between years 2006 and 2007, with the presence of $E$. coli at all points examined. Among the physical-chemical factors assessed, $\mathrm{pH}$ remained within established standards; chloride showed means above the limits at Points 2, 3, and 4 during the summer; conductivity showed values above $100 \mu \Omega / \mathrm{cm}$ at all points in the summer, with the exception of Point 1 . In the spring, an increase was seen in the means, which was not significant for all points.

In order to assess the behavior in the creek over the years, a general analysis was conducted, comparing the stations from each point examined in the years 2006 and 2007. All points showed significant differences for some of the variables assessed. During the fall and winter, Point 1 had a significant decrease in the number of dividing cells (MI), with $\mathrm{P}=0.011$ and $\mathrm{P}=0.010$. At Point 2, besides the decrease in MI, in the fall $(\mathrm{P}=0.019)$, the interphase anomalies were also significantly decreased in $2007(\mathrm{P}=0.009)$, and in the winter there was a 
decrease only in MI $(\mathrm{P}=0.019)$ as in Point 1 . At Point 3 , in 2007, there was a significant decrease in $\mathrm{MI}$ in autumn $(\mathrm{P}=0.011)$, winter $(\mathrm{P}=0.011)$, and spring $(\mathrm{P}=0.019)$. A decrease was also seen in IA in the fall $(\mathrm{P}=0.010)$ and spring $(\mathrm{P}=0.046)$; TA also decreased only in the fall $(\mathrm{P}=0.025)$. At Point 4, all stations had a decrease in MI in 2007 relative to 2006; in the fall, besides MI, there was a decrease in IA $(\mathrm{P}=0.009)$, but in the winter, TA was higher $(\mathrm{P}=0.033)$ in 2007 than in 2006 , as well as MA $(\mathrm{P}=0.032)$. At Point 5 , MI was lower only in spring $(\mathrm{P}=$ $0.025)$, which makes it stand out from all other points examined; IA were also decreased in the fall, winter, and spring of $2007(\mathrm{P}=0.013, \mathrm{P}=0.036$, and $\mathrm{P}=0.009$; respectively).

Based on the findings presented, it is concluded that, in 2007, the mean rain level in some stations was up to three times higher than in 2006, which partly explains the increase in anomalies in 2006, by the accumulation of toxic substances present in the creek, followed by their decrease in 2007.

\section{ACKNOWLEDGMENTS}

The authors thank their colleagues from Laboratório de Genética at Centro de Ciências da Vida e da Saúde, as well as the staff from Universidade Católica de Pelotas, who provided transportation for the sampling trips.

\section{REFERENCES}

Alba-Tercedor J (1994). The Entologist and the Problems of Aquatic Systems Degradation. In: Environmental Management and Arthropod Conservation (Jiménez-Peydró R and Marcos-García MA, eds.). Asociación Española de Entomologia, Valencia, 131-138.

American Public Health Association (APHA). American Water Work Association (AWWA). Water Polution Control Federation (WPCF) (1998). Standard Methods of the Examination of Water and Wastewater. 19th edn. Public Health Association Inc., New York.

Baumgarten MG and Pozza SA (2001). Qualidade de Águas: Descrição de Parâmetros Químicos Referidos na Legislação Ambiental. Fundação Universidade Federal do Rio Grande, Rio Grande.

Bickham JW, Sandhu S, Hebert PD, Chikhi L, et al. (2000). Effects of chemical contaminants on genetic diversity in natural populations: implications for biomonitoring and ecotoxicology. Mutat. Res. 463: 33-51.

Braga B, Hespanhol I, Conejo JGL, Mierzwa J, et al. (2002). Introdução à engenharia ambiental. Prentice Hall, São Paulo.

Companhia de Tecnologia de Saneamento Ambiental (CETESB) (2007). Variáveis de Qualidade das Águas. Available at [http://www.cetesb.sp.gov.br/Agua/rios/variaveis.asp]. Accessed October 22, 2007.

Conselho Nacional do Meio Ambiente (CONAMA) (2005). Resolução No. 357 de Março de 2005. Ministério do Meio Ambiente, Diário Oficial da União, Brasil. Available at [http://www.mma.gov.br/port/conama/res/res05/res35705. pdf]. Accessed September 12, 2007.

Egito LCM, Medeiros MG, Medeiros SRB and Agnez-Lima LF (2007). Cytotoxic and genotoxic potential of surface water from the Pitimbu River, northeastern/RN Brazil. Genet. Mol. Biol. 30: 435-441.

Esteves FA (1998). Fundamentos de Limnologia. Interciência, Rio de Janeiro.

Evandri MG, Tucci P and Bolle P (2000). Toxicological evaluation of commercial mineral water bottled in polyethylene terephthalate: a cytogenetic approach with Allium cepa. Food Addit. Contam. 17: 1037-1045.

Ferreira A and Cunha C (2005). Sustentabilidade Ambiental da Água Consumida no Município do Rio de Janeiro, Brasil. Rev. Panam. Salud Publica 18: 93-99.

Fiskesjö G (1988). The Allium test - an alternative in environmental studies: the relative toxicity of metal ions. Mutat. Res. 197: 243-260.

Irgang BE and Gastal Júnior CVS (1996). Macrófitas Aquáticas da Planície Costeira do RS. Universidade Federal do Rio Grande do Sul, Porto Alegre.

Lazutka JR, Stapulionyte A, Bjerketvedt DK and Odland A (2003). Seasonal variation in the frequency of abnormal anaphases and mitotic index values in wild populations of herb-Paris (Paris quadrifolia L., Trilliaceae): implications 
for genetic monitoring. Mutat. Res. 534: 113-122.

Leme DM and Marin-Morales MA (2008). Chromosome aberration and micronucleus frequencies in Allium cepa cells exposed to petroleum polluted water - a case study. Mutat. Res. 650: 80-86.

Matsumoto ST, Mantovani MS, Malaguttii AMI, Dias LA, et al. (2006). Genotoxicity and mutagenicity of water contaminated with tannery effluents, as evaluated by the micronucleus test and comet assay using the fish Oreochromis niloticus and chromosome aberrations in onion root-tips. Genet. Mol. Biol. 29: 148-158.

Ohe T, White PA and DeMarini DM (2003). Mutagenic characteristics of river waters flowing through large metropolitan areas in North America. Mutat. Res. 534: 101-112.

Pereira DG, Carvalho S and Fonseca CA (2002). Avaliação da genotoxicidade em planta do cerrado. Biotecnol. Cienc. Desenvolv. 29: 128-133.

Rank J and Nielsen MH (1997). Allium cepa anaphase-telophase root tip chromosome aberration assay on N-methyl-Nnitrosourea, maleic hydrazide, sodium azide, and ethyl methanesulfonate. Mutat. Res. 390: 121-127.

Reifferscheid G, Ziemann C, Fieblinger D, Dill F, et al. (2008). Measurement of genotoxicity in wastewater samples with the in vitro micronucleus test: results of a round-robin study in the context of standardisation according to ISO. Mutat. Res. 649: 15-27.

Rosa M (1985). Geografia de Pelotas. Ed. Universidade Federal de Pelotas, Pelotas.

Silva J and Fonseca MB (2003). Estudos Toxicológicos no Ambiente e na Saúde Humana. In: Genética Toxicológica (Silva J, Erdtmann B and Henriques JAP, eds.). Alcance, Porto Alegre, 70-84. 